\title{
Turkey-Africa Relations: Opportunities and Challenges
}

\author{
Yusuf Ibrahim Gamawa ${ }^{1}$ \\ ${ }^{1}$ Bauchi State University, Gadau, Nigeria \\ Correspondence: Bauchi State University, Gadau, Nigeria.Email: yusufgamawa@ymail.com
}

Received: October 07, 2017

Accepted: October 10, 2017

Online Published: October 15, 2017

\begin{abstract}
The Continent of Africa had been of great importance to many Countries outside Africa, Since the begining of the slave trade when European slave merchants invaded Africa and estalished the trade in human beings, which forced the migration of millions of Africans to America and the West Indies. Since then, the Continent had faced a continued influx of people for different purposes even after the abolution of slavery. The main attraction to Africa, has been its human and rich mineral resources scattered across the continent, as well as its vast market for foreign goods. This paper examines the relations between the republic of Turkey and countries of the African Continent, especially in 1990's and 2000's when the republic of Turkey began to develop interest to have relation with African countries. There were so many reasons that motivated and ignited the interest of Turkey in Africa all of a sudden, and this paper tried to present such reasons and also show how the republic of Turkey tried to establish such relations, the manner in which Turkey went about realising this objective of having deep economic, political and social relation with countries of the African Continent. The paper also tried to look at relations between Ottoman Turkey and Africa, though as a background to the present relations.It tried also to see what challenges there are in this relations, in the future or now, and also tried as much as possible to look at some policy suggestions regarding this symbiotic relations between Turkey and African countries. The paper argues that Pan Africanism poses a challenge to relations between Turkey and Africa and offered some policy suggestions that will deepen integration between Turkey and African States.
\end{abstract}

Keywords: Turkey, Africa, Opportunities, Challenges, Pan-Africanism.

\section{Introduction}

The continent of Africa has witnessed influx of different people from different countries in the past several centuries, and from continents outside Africa.The continious interest in the continent may have come about as a result of several reasons. The continent first saw the coming of the Europeans around the 15th Century, during the transatlantic slave trade era, during which millions of Africans were forcefully taken to Europe and America to work in the plantation in the West Indies and which resulted today in the emergence African American population in the US and other countries of Europe. After the abolution of the slave trade and the subsequent introduction of legitimate trade, the Europeans resumed their presence in Africa, first through Christian missionary activities and the European civilising mission in Africa, which had been dismissed by many scholars as a camouflage of the imperial profit and motive, and this was followed by the introduction of trade and commerce with the African people. 
Another significant event in the history of African relations with countries and peoples outside the African continent was the Berlin Conference, it was at the conference that the continent of Africa was partitioned between some European countries as colonies. This marked the begining of colonial conquest in Africa and the eventual establishment of colonial rule and the native authority system of administration throughout Africa by the British, French, Portuguese, Germans as well as the Italian, who divided the continent among themselves. The entire continent was subjugated into adopting the new system with brute force, with it, the entire framework of the traditional African societies and kingdoms was broken down, and a new imperial system of production was thus introduced. New methods of agriculture, and new crops were introduced with free African labour, an export oriented economy was established throughout Africa and was meant to feed the newly founded industries across Europe, which had emerged as a result of the industrial revolution ,particularly in England in the 1700's, with raw materials. This remained the basis of the relation between the Western colonial powers and Africa throughout the period of colonial rule, and what followed afterwards, was the gradual assimilation of the continent into the global imperialistic capitalist economy even after African nations had attained independence, the newly emerging states found themselves trapped in this system of global economic exploitation, and the never ending natural destiny of dependence on Western industrialised nations for technical assistance and socio-economic development of the continent which has remained illussive despite all the resources and pottentials present in the continent. The relationship till today has remained one that is marked by in commensurate development of the continent and the exploitation of its resources and peoples. Although many argued that the Africans had benefited from their relation with the Western nations, which the claim is sees in the modernisation of their societies and interms of western education, as against the primitive African societies that existed in the past. But many scholars also argued that it was European incursion into Africa that interrupted the indegenous natural process of the development of the Africans in all areas and even education, as a result of the contact with Islam on the continent, which had led to the founding of Islamic madrasas in many parts of Africa.

This indegenous development process of Africa is evidenced by archaelogical findings in the form of the existence of traditional technology, in traditional medicines, development of tools, and of iron ore local industries in Africa even in those times, is sufficient to support the natural development process of Africa. The exploitation of Africa continued till today, though in a very sophisticated and unpredictable manner, that today it is difficult to point out a particular way in which the continent is being sabotaged, but yet neo-colonialism is a phenomenum that is real in Africa, and it means the continious manipulation and mangement of the African economy and its growth by the Western industrialised capitalist nations and their cronnies, in league with indegenous Africans who act as intermedairies to this exploitative and manipulative system that is against the growth and development of Africa. The Western nations succeeded in creating a very vast market for the goods produced in their various countries, and thus turned Africa into a dumping ground for their manufactured goods and created an array services in the banking, insurance and communication sectors of the African economy which remains squarely under their control, and which has continued to attract other lesser developed nations to participate in the same venture.

The result is that today Africa has become a market not only to the Western industrialised nations,but to many emerging economies in Asia and other parts of the world such as China, Japan, India, South korea, Indonesia, Malaysia, Singapore, Israel and a host of others. And many other countries are seeking opportunities to come into Africa, and still strategising on how to tap from the vast resources of the continent. So today if Turkey is 
reaching out to Africa, it is because of the huge market pottential as well as for its enormous mineral resources, including its oil and gas deposits that is scattered across the continent. Turkey's Africa policy is designed to deepen relations for maximum benefit, and it remains an opportunity for Turkey to prove to Africa the genuineness of its Africa policy, different from what the continent had experienced in the past with other countries.

\section{Background of Turkey-African Relations}

There are basically two distinct Turkish conception of Africa, based on geographical divide; North Africa and Sub- Saharan Africa. However both conceptions have been shaped in the Turkish psyche by historical developments, mainly from Ottoman times, and this has been articulated in classical Turkish foreign policy towards the continent. Turkey has had strong relations with North Africa, as it was part of the Ottoman state, dating back to the 15th and 16th Centuries, while relations with sub-Saharan Africa is more of a recent development, begining from the 19th Century. North Africa and their close historical connection with the Ottomans, which created an understanding that it is part of the Turkish periphery, is also seen to be part of the broader Middle East, which Turkey feels very close. Whereas Sub- Saharan Africa is usually viewed as far away land, full of problem, hunger, diseases and civil wars.

Turkey's relations with Africa can be divided into three periods, the first can be regarded as the Ottoman empire relations with Africa until the establishment of the republic in 1923, and between 1923 and 1998, when relations between Turkey and Africa seemed to be non existent, and after 1998, when Turkey's interest in Africa became gradually revived, and in 2005, Turkey declared the year as the year of Africa. In 2008, the first ever TurkeyAfrica Cooperation Summit was held in Istanbul, with the participation of representatives from 51 African Countries. The old Ottoman empire had relations with North African states like Egypt, Libya, Tunisia, and Algeria, which were partially or totally included in the Ottoman state, states such as Sudan, Eriteria, Ethiopia, Djibouti, Somalia, Niger and Chad inclusive. The Ottoman's were also part of the balance of power system, having friendship and a defence pact with the Kanem Borno empire, which prevailed in todays northern Nigeria, Niger and Chad. The defense pact was signed in 1575, during the reign of Sultan Murad III, consequent upon which military equipment and defense officials were despatched to Kanem Borno to help the Mai's army in accordance with the defense pact between the two great empires. In 1849, the Ottoman sent a special envoy to Lagos when its first mosque was built. Confering on the community leader the title of "BEY", whose family is stil playing an important role in social and political life of Nigeria, the Shitta Bey family are still well known in Nigeria.

The Ottoman state had diplomatic representation in South Africa since 1861. The Ottomans sent Imams to Muslims of the Cape of Good Hope in 1863, upon the request of the community, resulting into a strong relationship between the Muslims of the Cape of Good Hope and the Ottoman state. After the founding of the Turkish republic in 1923, Turkey- Africa relations witnessed tremendous decline, arising mainly from internal problems from within Turkey, and also within the African Continent, which at this time was going through the painful period of Colonial rule. Although during the cold war period, Turkey began to consider its relations to Africa with importance, and began establishing links with the North African Countries economically and politically. However, these relations were shaped by the conditions of the cold war bipolarity, and thus were at odds with the historical public sentiment toward the continent. At Ghana's independence in 1957, Turkey recognised Ghana and opened an Embassy, and subsequently recognised all newly independent states, established diplomatic relations and opened Embassies in many of them. However this was not seen as a long 
term significant relationship and Turkey was not involved in African Affairs. M.Ozkan (2010).

\section{Turkey and Africa Today}

In 1998, the republic of Turkey came up with its "opening up to Africa policy". And in 2005, Turkey declared the year as "The Year of Africa", which was followed by the Turkey-Africa Cooperation Summit held in Istanbul in 2008, which proved to be a very important stage in the history of Turkey - Africa relations. At this Summit "The Istanbul Declaration on Turkey- Africa Partnership: Cooperation and Solidarity for a Common Future" and "Cooperation framework for Turkey- Africa Partnership" were unanimously accepted. 49 countries participated in the summit, including 6 Presidents, 5 Vice Presidents, 7 Prime Ministers, 12 Ministers, 11 International and Regional Organisation representatives including the African Union. These African countries at the end of the summit declared the republic of Turkey as a "strategic partner". Since then, Turkey attached great importance to the development of bilateral relations and rapproachment with African countries, and the establishment of new diplomatic missions in African countries which it hitherto had no relations with, paying mutual visits, having contacts at all levels, creating cooperation mechanisms and signing necessary Agreements. Turkey increased the number of its missions and opened new embassies in Tanzania, Ivory Coast, in 2009. Cameroun, Mali, Ghana, Uganda, Angola and Madagascar in 2010. While Zambia, mozambique, Mauritania, Zimbabwe, Somali, Gambia and South Sudan were opened in 2011. Niger, Namibia, Burkinna fasso and Gabon were opened in 2012, bringing Turkey's mission in the African Continent to a total of 31. In recent years, reciprocal high level visits have been made between Turkey and African countries. Turkey's President, Abdullah Gul paid visits to the African countries of Ghana and Gabon in 2011, Kenya and Tanzania in 2009, Congo, Cameroun and Nigeria in 2010. Prime Minister Erdogan of Turkey paid visits to Ethiopia, Sudan, Somali and South Africa. And on the other hand African Heads of States and Presidents of Chad, Somali, Nigeria, Tanzania, Uganda, Zambia, Mauritania and Djibouti also visited the republic of Turkey as a result of Turkey's first step in establishing relations with countries of the African continent. Orsam Report (2012)The first overseas visit of 2013 by Turkey's Prime Minister Recep Tayyip Erdogan was to the three Francophone West African countries of Gabon, Niger, and Senegal. He was accompanied by 250 businessmen. Gabon has oil resources, while Niger is an important source of uranium. Turkey has begun building its first nuclear reactor and plans to build two more by 2023. According to Ali Engin Oba, a former Turkish ambassador in Africa: "Certain groups in Africa are already showing efforts to break away from the influence of the big colonizing powers. Those groups are aware of France's economic problems and could guess that France would not continue its former level of interest in Africa because of those problems. So, they are trying to develop relations with powers that may want to develop economic, social and cultural solidarity with them, including Turkey. Courcy's Brief (2013)

\section{Turkey's New Foregn Policy and the States in Africa}

In discussing Turkish foreign policy, geographical location must be taken into consideration. Turkey is located at the crossroad of three different continents of Asia, Europe and Africa, and has as a result interacted with people from the three different continents. Africa is a huge continent with rich natural resources, vast agricultural arable land and human resources. There are 53 countries in Africa, and about $12 \%$ of the world population live on the African continent. Production of good and services in the continent is $3.3 \%$ in 2010 , Africa's population is expected to be more than 1 billion, which would represent $15.3 \%$ of the world's population. The economic growth rates in Africa in 1996 and 1998 had consecutively been $5.9 \%$ and 3.4\% representing more than that of the world's average growth rates. Africa is very rich in natural resources, and 
there is need for the natural resources of the country to be exploited, it is a huge market for traders and contractors to do bussiness and invest. Many countries have strong foothold in Africa, Turkey is not among these countries. Africa is considered to be the continent of the future as indicated by the statistical figures above.S.Z.Karaca (2000) The Americans, British, Germans, French, Italians, Chinese, Japanese and many others are going to Africa, and there is strong competition for control and influence among these powers. But despite all these, there is still a place for Turkey in most African countries to establish new contacts and coperations as well as to further and develop all kinds of existing Bilateral relationships for mutual interest. Turkey with its big pottential for development has many things to share with friendly foreign nations. The model and level of Turkey's industrial development is more suitable for the economic development of African countries. Statistics on trade between Turkey and African states shows that Turkey's exports to Africa rose from 748 Million dollars in 1990, to 1.8 Billion in 1998, while its import rose from 800 Million USD IN 1990, to 1.7 Billion USD IN 1998. Exports increased by $115 \%$, and imports by $104 \%$. S.Z.Karaca (2000)The African import market has a volume of 134 Billion in 1998, and Turkey's share was only 1.8 Billion or $1.4 \%$, in order for Turkey to make sustained efforts to improve its trade transaction and economic cooperation, Turkey must have more developed relations with African countries. And as a result, to achieve this, the government of Turkey decided to implement a new plicy of openning up to Africa, to overcome the difficulty and obstacles in promoting its relations with Africa, and an action plan was prepared to implement this policy. S.Z.Karaca (2000)

\subsection{Political Measures of the Action Plan}

- Realisation of high level visits from African Countries.

- Establishment of political consultation mechanisms at foreign ministry level.

- Intensification of contacts with African countries within International organisations such as UN, OIC etc.

- Mutual Inter- Parliamentary visits.

- Realisation of humanitarian assistance.

- Contribution to various technical assistance programmes.

\subsection{Economic Measures of the Action Plan}

- Conclusion of Agreements of trade, technical, economic and scientific cooperations, prevention of double taxation and mutual promotion and protection of investments inorder to completethe legal frame work of economic and trade relations.

- Invitation of Technical ministers form Africa such as ministers of trade, industry, health, agriculture and education

- Invitation of experts to short term training programmes in technical fields.

- Organisation of technical assistance for African countries.

- Realisation of Turkey's membership in the African Development Bank as a non regional member.

- Realisation of Turkey's membership as share holder in the African Exports and Imports Bank.

- Exchange of visits by bussinessmen.

- Creation of a joint Bussiness council or Chambers of Commerce by encouraging contact among private sectors. Orsam Report (2012) 


\section{Turkey's Soft Power Approach Towards Africa}

The institutionalisation of the initiative of the new policy of opening up to Africa, remained a big challenge and yet important on for Turkey, as it will determine the failure or success of the policy. This is despite the fact that the action plan had identified step and areas upon which the plan could be implemented. And it was generally thought that mere encouragement of bussinessmen and international contractors to do bussiness and invest is not enough, Turkey's approach considers the importance of cooperation in education and cultural fields, if openning up to Africa policy is to succeed. Turkey's soft power approach considered three major areas of cooperation, and this includes; Education, trade/ economic realations and Humanitarian aid as the most important.

\section{Cooperation in Education and Cultural Fields}

In the past two decades there has been influx of African students to Turkey into Turkish Universities to study through the initiative of the Turkish government, sometimes under the Bilateral education Agreement with some African countries, through the Inter-govermental Exchange of scholarship. These students have been required to acquire speaking; reading and writing competence in Turkish language, to enable them integrate and function fully within the Turkish society. Turkish Nile University was founded in Nigeria, while Turkish International Colleges were strategically established in important African countries such as Kenya, Senegal and Nigeria.

\section{Humanitarian Aid}

Aid remained one of the strongest elements in Turkey's overall policy towards Africa in particular. The Turkish Aid Agency, the Cooperation and Development Administration of Turkey, operates in Africa, with offices located in Addis Ababa, Khartoum and Dakar, as part of Turkey's development aid to Africa. Turkey has promised to provide technical assistance to African countries through such cooperation, and is striving to open affiliate offices in other African countries to cement cooperation with Africa on certain priorities which the Turkish President Abdullah Gul identified as "Health, Education, Agriculture, Enviroment, Infrastructure and capacity building". Through some International organisations like the UN World Food Programme, Turkey has donated 7.5 Million Dollars to various African countries. In 2008, 3.5 Million USD was donated for a similar purpose through the world food programme. When Turkey hosted the Least Developing Countries Summitat Istanbul in 2007, it committed 20 Million USD for the development aid of these countries which numbered 49, and 33 of which are African countries.

\section{Trade and Economic Relations}

According to the Turkish Confederation of Bussinessmen and Industrialists, through its Turkey -Africa bussiness meetings, African countries are mostly demanding furniture, apparels, durable house products, home textiles, processed food, packaging devices, iron-steel, electrical devices and construction materials. The Turkish Bussinessmen Confederation has always underlined the importance of investing in drilling and construction industries. The current nature of relations is not exhaustive and the cooperation is yet to be fully explored. Turkey's import from Africa includes oil, raw material, gold and minerals. Turkey's approach to developing trade with African nations differ from those of other countries seeking opportunity on the continent, and whose overiding interests are Africa's oil resources. Africans seem to be interested in Turkey's agricultural expertise, and Turkey carries non of the free market capitalist baggages aimed at securing the best deal at any cost by those countries, a policy which Africans so resent, by concentrating on lower profile development issues such as agriculture. Turkey's iniatiatives arguably carry the promise of effecting genuine change in the lives of the masses of Africans. Turkey's trade volume with Africa was only 5.4 Billion USD in 2003; since then it steadily increased more than two fold exceeding 12 Billion USD in 2007. Turkey's total global trade volume 
stands at about 300 Billion, Turkey aims to make its trade volume with Africa to about 30 Billion by 2010 . Contracting services provided by Turkish firms alone in those African countries have reached a total of 18 Billion USD. The amount of direct Turkish investment in African countries exceeds 500 Million USD, and is expected to increase in the future. Turkey became a non regional member of the of the African Development Bank, and African Export/ Import Bank such membership is expected to open new areas of cooperation which could assist contracting firms from Turkey undertaking large infrastructural projects on the continent.M.Ozkan (2010) The tables below shows the volume of trade between Turkey and some selected African countries between 1997 and year 2008 .

\begin{tabular}{lllllllllllll}
$\begin{array}{l}\text { Exports } \\
\text { Million }\end{array}$ & $\mathbf{1 9 9 7}$ & $\mathbf{1 9 9 8}$ & $\mathbf{1 9 9 9}$ & $\mathbf{2 0 0 0}$ & $\mathbf{2 0 0 1}$ & $\mathbf{2 0 0 2}$ & $\mathbf{2 0 0 3}$ & $\mathbf{2 0 0 4}$ & $\mathbf{2 0 0 5}$ & $\mathbf{2 0 0 6}$ & $\mathbf{2 0 0 7}$ & $\mathbf{2 0 0 8}$ \\
US\$ & & & & & & & & & & & & \\
\hline $\begin{array}{l}\text { South } \\
\text { Africa }\end{array}$ & 72 & 73 & 59 & 72 & $\mathbf{7 8}$ & $\mathbf{8 8}$ & $\mathbf{1 2 2}$ & $\mathbf{1 9 1}$ & $\mathbf{3 1 6}$ & $\mathbf{5 9 9}$ & $\mathbf{6 5 4}$ & $\mathbf{1 2 3 9}$ \\
\hline Nigeria & 17 & 24 & 38 & 46 & $\mathbf{7 0}$ & $\mathbf{6 3}$ & $\mathbf{6 7}$ & $\mathbf{8 1}$ & $\mathbf{9 9}$ & $\mathbf{8 4}$ & $\mathbf{1 3 4}$ & $\mathbf{2 8 1}$ \\
\hline Sudan & 26 & 35 & 34 & 38 & $\mathbf{5 5}$ & $\mathbf{6 0}$ & $\mathbf{6 4}$ & $\mathbf{8 9}$ & $\mathbf{1 4 6}$ & $\mathbf{2 1 7}$ & $\mathbf{1 8 0}$ & $\mathbf{2 3 5}$ \\
\hline Kenya & 10 & 13 & 12 & 8 & $\mathbf{1 1}$ & $\mathbf{9}$ & $\mathbf{1 4}$ & $\mathbf{1 8}$ & $\mathbf{5 1}$ & $\mathbf{8 6}$ & $\mathbf{9 9}$ & $\mathbf{2 3 4}$ \\
\hline Angola & 3 & 3 & $\mathbf{3}$ & 5 & $\mathbf{9}$ & $\mathbf{1 2}$ & $\mathbf{1 4}$ & $\mathbf{2 3}$ & $\mathbf{2 7}$ & $\mathbf{4 5}$ & $\mathbf{4 8}$ & $\mathbf{1 8 3}$ \\
\hline Total & $\mathbf{1 2 8}$ & $\mathbf{1 4 8}$ & $\mathbf{1 4 6}$ & $\mathbf{1 4 6}$ & $\mathbf{2 2 3}$ & $\mathbf{2 3 2}$ & $\mathbf{2 8 1}$ & $\mathbf{4 0 2}$ & $\mathbf{6 3 9}$ & $\mathbf{1 0 3 1}$ & $\mathbf{1 1 1 5}$ & $\mathbf{2 1 7 2}$ \\
\hline
\end{tabular}

Imports

\begin{tabular}{lllllllllllll}
\hline $\begin{array}{l}\text { Million } \\
\text { US\$ }\end{array}$ & 1997 & 1998 & 1999 & 2000 & 2001 & 2002 & 2003 & 2004 & 2005 & 2006 & 2007 & 2008 \\
\hline $\begin{array}{l}\text { South } \\
\text { Africa }\end{array}$ & 184 & 153 & 124 & 172 & 346 & 212 & 336 & 1007 & 1260 & 1794 & 173 & 1503 \\
\hline Nigeria & 17 & 3 & 5 & 133 & 229 & 182 & 224 & 195 & 235 & 381 & 494 & 522 \\
\hline Sudan & 10 & 12 & 8 & 5 & 2 & 13 & 8 & 13 & 8 & 8 & 9 & 10 \\
\hline Kenya & 4 & 2 & 2 & 3 & 4 & 3 & 2 & 2 & 2 & 4 & 13 & 13 \\
\hline Angola & 1 & 1 & 1 & 1 & 1 & 1 & 1 & 1 & 10 & 27 & 1 & 17 \\
\hline Total & 216 & 171 & 140 & 314 & 582 & 411 & 571 & 1218 & 1515 & 2214 & 2690 & 2065 \\
\hline
\end{tabular}

Source: Turkish PM, the Undersecretary of Customs website, http://www.gumruk.gov.tr (14.12.2009);totals may not add up, due to rounding.

\section{Activities of Turkish State Agencies and NGO's in Africa}

Since the adoption of the policy of opening up to Africa, many state agencies started to play a very active role in many African countries. The Turkish International Cooperation Agency (TIKA) AND THE Directorate for Religious Affairs of Turkey(Diyanet) remain important and their activities reflect the level of Turkish involvement in Africa. Part of the Turkish policy is humanitarian aid to Africa, and this is despite the fact that Turkey is itself a recipient country. The humanitarian aid policy became more viable after TIKA as an organisation had been formed in 1992. It is the governments offical development cooperation agency, and had opened development offices in twenty one African countries with a view to offering assistance through technical projects and humanitarian activities. It was initially established to help transition of the states in Central Asia, Caucasus and the Balkans, but from 2003 it turned into a more global aid agency and expanded its areas of 
operation paralel to Turkey's diversfying foreign engagements. Between 1992-2002, TIKA had conducted 2,346 projects and activities throughout Africa, its total number of projects increased in 2003 to 2,780 mostly in Africa and the Middle East. M.Ozkan \& B.Akgun (2010) It sponsored projects in Africa which rose from 45 in 2005, to 150 in 2006. TIKA's projects and activities in Africa were designed to serve long term purposes, which include among other things, the development of social infrastructure, cultural cooperation and communication, economic infrastructure and to a less degree, provide support in urgent humanitarian crises. In accordance with this, TIKA initiated an agricultural development programme to be implemented in 13 African countries. M.Ozkan \& B. Akgun (2010)

Turkey's policy towards Africa has gone far beyond political and economic areas, Diyanet had only recently invited religious leaders from African countries for consultation and cooperation. The Religious Leaders Meeting of African Continent Muslim Countries and Societies was held in Istanbul in 2006, with the participation of representatives from 21 African countries. The Turkish conception of of Islamic understanding is compatible with Democratic values and provides an alternative to that fostered in Africa, by a number of Muslim states. In the past, the civil society played a limited role in Turkish foreign policy, but for the first time, the civil society is playing an active role, promoting a policy backed by the state, especially of the relations between Turkey and Africa, than any field of Turkey's foreign policy. Organisations such as the the Confederation of Turkich Bussineesmen and Industrialists of Turkey (TUKSON), AND THE International Aid Organisation and the Foundation for Human Rights and Humanitarian Relief (IHH), Have not only paved the way for Turkey- Africa relations, but have indeed accelerated the process for the development of such relations. These organisations raised raised awareness about Africa, both for its economic opportunities, and for political and humanitarian engagements. The traditional Turkish image of Africa, as one of hunger, poverty and disease became reformulated and articulated by Turkish civil society organisations present in Africa. M.Ozkan \&B.Akgun (2010)

TUKSON had recently organised five International Trade Summits to boost Turkey's economic relations with 3 African countries. These summits brought Africa to the attention of Turkey, and created an avenue for both sides to intereact and explore possible forms of cooperation. TUKSON represent 11, 500 bussinessmen throughout Turkey. Today 134 TUKSON members have significant investments in Africa, members have opened Turkish schools totalling 60 in 30 different countries across Africa. Turkey's flourishing new bussinessmen also provide funds for humanitarian Works and relief efforts undertaken by Turkish NGO's in the continent. The IHH, A Turkısh Humanitarian Organisation, operating in about 112 countries including Africa, became a Pioneer charity NGO in Turkish society, creating awareness of human suffering to the larger Turkish society, encouraging charity to poor African communities. The IHH also ientified HIV/AIDS as an area in health, as well as blindness due to cataract, and made donations and conducted operations to victims. It launched a programme to cure blindness caused by cataract, and had carried out operation to about 35,000 people across the African continent. M.Ozkan \& B.Akgun (2010) Turkey's African opening was found beneficial by Africans and as a result many African countries are considering Turkey as a partner despite mixed feelings.

\section{Turkey-Africa Relations and Challenges of Pan Africanism}

Pan-Africanism is perceived as the need to mobilise peoples of Africa against racism, it is a political philosophy behind current efforts to achieve political unity in Africa through the instrumentality of the African Union. S.Okhonmina (2008) The transatlantic slave trade was a significant landmark in the annals of African history, it 
produced forced migration of millions of Africans as slave labourers to Europe, the Americas and the Carribean. The carry over of Africans to the new world has kept alive their African roots. It is believed that this was what laid the foundations of Pan-Africanism and Black nationalism in the United States and West Indies. It began with the founding of the African Association in London in 1897 and the Pan-African Conference 3 years later. Dr W.E.B Dubois had between 1900 and 1945 organised and participated in a series of Pan-African Congresses in the US and Europe, which brought togather peoples of African descent from Americas, Africa and Europe. In the 1920's, Marcus Garvey also began to promote African nationalism with the motto "Africa for Africans". The Africans after independence shared the common experience of subjugation to slavery, colonialism and imperialism, this experience and memories of marginalisation and socio-cultural and racial affinities developed a collective solidarity- a sense of oneness and concioussness of belonging to Africa. This became a powerful mobilising and unifying force for African peoples and societies rooted in Pan-Africanism. P.G Adogamhe (2008)

The Pan-African movement was essentially a protest of Black people against their exploitation, against racism, and for the dignity and upliftment of the Black people. A. Bujra (2002) African states are systems of patronage, their external relation is designed to generate funds that oil this network of patronage in the form organisations and transnational bodies and NGO'S. Most Africans identify and place more emphasis on the external causes of their crises, even though colonialism created the basic conditions of these crises, of dependent economies, divided people, undeveloped human resources etc. The international commodity market and the financial system and the dominant role of western and transnational corporations are formidable barriers which weaken African countries, and Africa finds it difficult to economically develop, create nation states and develop their human and natural resources. Institutions and Donor countries intervened in African economies to help Africans overcome their crises, but such interventions simply perpetuated the unequal and exploitative relationship between Africa and the global system. A.Bujra (2002) Pan-Africanism has in the 21st Century, transformed into a mobilising ideology and a development blue print. The idea of a United States of Africa was first muted in a Pan-African meeting in Cairo in 1960, by Dr Kwame Nkrumah. The African Union was therefore a product of many years of Pan Africanist aspirations. It is the expression of Pan Africanism as a structural working frame work for action in regard to the multiple issues facing the african people. S.Okhonmina (2008) The former President of Nigeria, at the AU meeting said "The goal of the African Union must be the unity of all Africans and people of African descent in the diaspora. Such unity is merely a means to the ultimate goal, which is the development and transformation of our people and Continent." S.Okhonmina (2008)

\section{Turkey-Africa Relations and Mutual Benefits}

- Turkey's experience as a medium-sized country that has both modernized politically and developed economically is one that resonates with many African countries and, in point of fact, is probably a more reasonable model for their emulation than China or India, both of which are unique in their global standing.

- African states stand to benefit from Turkey's new interest in their continent insofar as the addition of yet another suitor enables them to diversify their sources of foreign investments and other partnerships so as to not become too dependent on the United States, France, China, Britain, India, or any other single outside actor. The key, however, is that Africa's leaders must be prepared to approach this opportunity strategically - a feat that many have not always been particularly adept at if history is any indication.

- Not only does Africa clearly provides a new market for the growing Turkish economy, but, at a time when 
the Turkey's eventual integration into the European Union is very much in doubt, the nations of the continent provide Ankara with a much-needed avenue to diversify its diplomatic portfolio. The recalibration of Turkey's foreign policy as well as the country's bolder forays into global politics - as witnessed by the recent attempt by Prime Minister Erdoğan and Brazilian President Luiz Inácio Lula da Silva to broker a deal in the standoff over Iran's nuclear ambitions - will have considerable impact on the international system in general and regional balance of power in particular, to say nothing of the NATO alliance which Turkey has been a member of since 1952.

- Turkey's reentry into Africa does not come without its complications. In November, 2012 for example, controversy was stirred when Sudan's International Criminal Court-indicted ruler, Umar Hassan al-Bashir, was invited to an economic and commercial cooperation conference being held in Istanbul. Faced with blistering global criticism for planning to host the subject of an international arrest warrant charging him with five counts of crimes against humanity and two counts of war crimes for his role in the humanitarian disaster in Darfur, Turkish officials prevailed upon the Sudanese ruler to cancel his visit less than twenty-four hours before he was due to arrive. Nonetheless the episode underscored the potential that American and European governments might find their ability to impose reform agendas and other leverage in Africa diminished as a result the arrival of the Turks on the scene.

- While the Turkish example of secularism in politics in the modern period is probably one worth considering for Africans who have been faced with religiously-stoked communal tensions such as those in Nigeria over the imposition of Islamic law in northern states, the growing concern that the AKP government in Ankara may be chipping away at that very secularism is reason enough for a cautionary attitude concerning Turkey's increasing engagement on the continent. The geostrategic implications of a Middle Eastern power with an Islamist orientation acquiring a greater stake in Africa cannot be ignored. J.P.Pham (2010)

\section{Policy Recommendation}

- Turkey should have different ways of considering and dealing with Africa and African issues. Africa is not one or united. A divisive and regional approach is necessary for success. In addition to North Africa, one can see four regions: south, central, west and east Africa. Each has different characteristics, mostly due to varying ethnic-religious compositions and colonial backgrounds.

- A gateway country-based approach is also needed. In each region, there are some key countries; if possible, Turkey should pay special attention in developing bilateral relations with them without sidelining others. Tentatively, South Africa, Ethiopia, Nigeria, the Democratic Republic of Congo, and Senegal can be named. The more Turkey strengthens its relations with these key countries, the more it can feel secure in Africa.

- The different colonial backgrounds of the countries in Africa play quite decisive roles in African politics. British, Francophone, Portuguese and Spanish Africa are all different in their ways of thinking and their approach to issues. This fact should be taken seriously while developing relations with

- each country.

- There exist two types of leadership in Africa. One is represented by the older generation, those who led the processes of decolonization and independence for their countries. The other is the second generation: 
leaders after the independence. While the former are more or less inward-looking and suspicious of foreign help, the latter are for the most part forward-looking and willing to work with outside powers. Intensifying relations with the latter group could make Turkey's relations with Africa more meaningful and long-lasting.

- Turkey has recently developed its relations with Africa at the institutional level, involving itself in such bodies as the African Union and Africa Development Bank. Ankara should continue to strengthen ties with the existing institutions in Africa (NEPAD, IGAD, SADC, ECOWAS, etc.) as part of its long-term policy. Turkey should envision and implement the Turkey-Africa Cooperation Summit as a venue for forging a common, institutionalized form of Turkish-African relations.

- Turkey's Africa policy should have global dynamics. Following on, and if possible participating in, such inter-continental groupings as the India-Brazil-South Africa Dialogue Forum (IBSA Dialogue Forum) is the best way to link relations with Africa and the world. This linkage could expand boundaries of relations between Turkey and Africa by adding an international dimension.

The most persistent issue looming between Turkey and Africa is the lack of information about the other on both sides. Three strategies could be implemented:

A. Promote support for sending exchange students to studying in each other's countries and learn about each other. This will bridge the societal and informational gap.

B. Exchange academics between universities. Especially in southern Africa, there is a lack of experts on the Middle East and Turkey, and the same is true for Turkey about Africa. Creating an African chair for African professors in one (or more) of the Turkish universities that offer education in English would be a good start. This might lead to an institute in the long run.

C. Support cooperation between African and Turkish think-tanks. Organizing joint conferences and publications about both sides on Turkish and African issues would create awareness, equally important on both sides.M.Ozkan (2008)

There is need to introduce the study of languages in both Turkey and Africa, some Universities, even as regional centres, would be encouraged to offer courses in Turkish language. And on their part, Turkish Universities could also embark on a program of introducing the major African lingua franca, such as Kiswahili and Hausa. All the three languages are important in enhancing cooperation, not only as languages of wider communication in their respective regions, but also as carriers of their cultural heritage. Africans are unaware that the Turkish language is spoken over large swathe of Central Asia, with speakers numbering 141 Million, equally Turks are unaware that there are over 100 Million speaker of Kiswahili, spread over East and Central Africa, and well over 200 Million speakers of Hausa mainly in Nigeria, spread all over West Africa. M.Bakari (2005)

\section{Conclusion}

Relations between Turkey and Africa started from Ottoman times, even though these relation was interrupted by certain changes, both in Turkey and in Africa as well. The end of world war I saw the dissentegration of the Ottoman empire and the Emergence of modern Turkey. In Africa, it was the Berlin conference that saw to the collapse of many Empires that hitherto had relations with the Ottomans such as Kanem. Relations remained limited between Modern Turkey and the emerging new African states until the 1990's and the 2000's. It was during this period that Turkey realised the importance of the African continent to its economy and politics and carefully designed and came up with an active policy framework to deepen its relation with Africa, which seems 
to be way on course. But this relation is certainly not without some challenges and in this regard the Pan Africanist aspiration of the Africans remains a big challenge to Turkey and any foreign country on the African continent now and in the future, despite the flexible global integration policy within the continent. Pan-Africanism is at the heart of Africa's economic and political trasformation programme for over a century, and all major economic and political development programmes in Africa are centred on Pan-African ideals. A typical example of the misunderstanding in the perception and relations between Turkey and Africa can be seen in the recent activities of Turkish bussinessmen in eastern Nigeria where the sided and identified with IPOB, an ethnic separatist group. The actions of the bussinessmen led to the call for the closure of Turkish Mission in Nigeria, the Embassy had to clearly disaasiciate itself from the activities of its citizens in Nigeria but even then it had already created bad feeling among Nigerians about Turkey.

\section{References}

Abdallah Bujra. (2002) .Africa: From OAU to the African Union, African Centre for Research and Training in Social Development.

Ama Biney.(2008)The Legacy of Kwame Nkrumah in Retrospect,Journal of Pan African Studies, Vol-2, No-3.

Aremu Johnson Olaosebikan, Nkrumah and the Proposed African Common Government, African Journal of Political Science and International Relations, 2011.

Country Profile:Turkey,(2008) Library of Congress, Federal Research Division, www.icweb2.loc.gov, .

Courcy's Intelligence Brief, (2013) A Startegic Early Warning, 9 January.

Mehmet Ozkan, (2008) Turkey's Rising role in Africa, Turkish Quaterly Policy, Vol 9, No 4.

Mehmet Ozkan, (2008) Turkey Discovers Africa: Implication of Prospects, SETA Foundation of Political, Economic and Social Research.

Mehmet Ozkan, Birul Akgun, (2010) Turkey's Opening to Africa, Cambidge Journal.

Mohammed Bakari,(2005)Turkey-African Social and Cultural Relations: Reflections.

Paul G. Adogamhe, (2008) Pan Africanism Revisited; Vision and Reality of African Unity and Development, African Review of Integration, vol 2.

Peter Pham , (2010) Turkey's Return to Africa, Family Security Matters, www.familysecuritymatters.org

Pre-Colonial Sub-Saharan African Civilisation and Evolution with Wild Life. www.libserv.5.tut.ac.za

Salih Zeki Karaca, (2006) Foreign Policy, A Quaterly of Foreign Institute.

Samuel G. Amoo,(1992)The OAU and African Conflicts: Past Succeses, Present Paralysis and Future perspective, Institute of Conflict Analysis and Resolution George Mason University.

Sean Kay(2007). Globalisation, Power and Security, Ohio Weslayan University, Delware, USA.

Stephen Okhonmina, (2008) African Union: Pan Africanist Aspirations and Challenges of African Unity, University of Benin.

ORSAM, (2012)Turkey In Africa: The Implementation of the Action Plan and Evaluation After Fifteen Years, No124.

\section{Copyrights}

Copyright for this article is retained by the author(s), with first publication rights granted to the journal. 